\title{
Molecular mechanisms of epithelial to mesenchymal transition in tumor metastasis*
}

\author{
Artur Nieszporek\#, Klaudia Skrzypek\#® Grazyna Adamek and Marcin Majka田 \\ Jagiellonian University Medical College, Faculty of Medicine, Institute of Pediatrics, Department of Transplantation, Kraków, Poland
}

Epithelial to mesenchymal transition (EMT) is a process where cancer cells lose their epithelial features, the cytoskeletal architecture is re-organized, the cell shape changes and cells activate genes that help to define a mesenchymal phenotype, which leads to an increased cell motility and dissemination of tumor to distant metastatic sites. This review describes different signaling networks between microRNAs and proteins that regulate EMT in tumor growth. Activation of EMT is mediated via a series of paracrine signaling molecules. WNT, TGF- $\beta$, NOTCH and SHH signaling pathways play crucial roles in activation of EMT-related transcription factors, such as SNAIL, SLUG, ZEB1/2 or TWIST. Recent data provide evidence that crosstalk between microRNAs, long noncoding RNAs and EMT-transcription factors is a crucial event in EMT regulation. MicroRNAs also affect the level of proteins responsible for cellular contact, adhesion and cytoskeletal proteins, which induces changes in the epithelial to mesenchymal phenotype transition. Understanding those signaling networks may help to identify novel biomarkers or develop new treatment strategies based on microRNA therapeutics in the future.

Key words: epithelial to mesenchymal transition (EMT), tumor, metastasis, microRNA, transcription factors

Received: 25 October, 2019; revised: 17 December, 2019; accepted: 19 December, 2019; available on-line: 29 December, 2019

『e-mail:mmajka@cm-uj.krakow.pl (MM)

klaudia.skrzypek@uj.edu.pl (KS)

\#These authors contributed equally to this work

${ }^{*}$ Acknowledgements of Financial Support:

The costs of the article published as a part of the 44th FEBS Congress Kraków 2019 - From molecules to living systems block are financed by the Ministry of Science and Higher Education of the Republic of Poland (Contract 805/P-DUN/2019).

This study was supported by research grants from the National Science Centre (Poland) 2015/17/D/NZ5/02202 and 2013/09/B/ NZ5/00769, and the New Horizons in Oncology Programme from the Jagiellonian University Medical College.

KS was a recipient of the Foundation for Polish Science's START scholarship for outstanding young scientists and the Polish Ministry of Science and Higher Education's scholarship for outstanding young scientists.

Abbreviations: APC, adenomatous polyposis coli; ECM, extracelluIar matrix; EMT, epithelial to mesenchymal transition; GSK-3 $\beta$, glycogen synthase kinase $3 \beta$; MET, mesenchymal to epithelial transition; RTK, receptor tyrosine kinases; TF, transcription factor; TGF- $\beta$, transforming growth factor $\beta$

\section{INTRODUCTION}

Cancer can be defined as a growth abnormality, characterized by uncontrolled proliferation of abnormal cells that can invade normal tissues and organ boundaries and then eventually spread throughout the body. In the first step of the tumorigenesis process, called "tumor initia- tion", genetic alteration of a single cell causes abnormal proliferation, which consequently leads to the outgrowth of a population of clonally derived tumor cells. During tumor progression, successive genetic changes confer growth advances (hyperplasia), morphological and functional deviation (dysplasia), altogether driving progressive transformation of the normal human cells into highly malignant derivatives, finally able to invade neighboring tissues and give distant metastases (Cooper, 2000; Hanahan et al., 2000; Ryan \& Faupel-Badger, 2016).

These mutations, driving to oncogenesis, are related to two opposing groups of genes: the oncogenes and tumor suppressor genes, mostly connected with regulation of proliferation and cell cycle. Oncogenes are created by a single, dominant mutation event, which has an activating capability and leads to gain of function, while a mutation in the tumor suppressor genes of both gene loci is needed to drive a loss of gene function (Weinberg, 1994).

On the other hand, cancer cells are in some aspect liberated from dependence on signals derived from the normal tissue microenvironment, for example those connected with acquiring the ability of tumor cells to expand in number. This capability can be achieved by an increased rate of cell proliferation: upregulation of signals promoting proliferation and decreased antigrowth signaling, but also by cancer cells resistance to death, mainly apoptosis (Hanahan et al., 2000; Hanahan \& Weinberg, 2011).

In order to fuel growth and division of cancer cells more efficiency, tumor development is also connected with adjustment of the energy metabolism. Recent reports claim that this reprograming can be related to a deregulated uptake of glucose and amino acids, opportunistic modes of nutrient acquisition, utility of glycolysis and TCA cycle intermediates, increased nitrogen demand, alterations in metabolite-driven gene regulation, and metabolic interactions with the microenvironment (Pavlova \& Thompson, 2016).

To access the unlimited possibility of cell divisions, cancer cells also need to overcome a progressive shortening of telomeres, i.e. sequences responsible for protecting the ends of chromosomal DNA during successive cycles of replication (Hanahan et al., 2000).

When the tumor size is larger than $2-3 \mathrm{~mm}^{3}$ (Sherwood \& Parris, 1971), it requires a new system of blood vessels to provide nutrients and other factors required for further growth. Therefore, tumors appear to activate the process of angiogenesis by changing the balance of expression between angiogenesis inducers and the countervailing inhibitors (Hanahan \& Weinberg, 2011).

Another, worth mentioning aspect of cancer progression, is interaction of tumor with the immune system. During the early stages of tumor development, the effector immune cells eliminate immunogenic cancer cells 
which leads to a continuous selection and promotion of more aggressive clones with reduced immunogenicity or those able to secrete immunosuppressive factors (Fouad \& Aanei, 2017). Most tumors progress to a state of chronic inflammation, stimulating cancer cell proliferation and metastasis by: genomic instability, epigenetic modification, induction of cancer cell proliferation, enhancement of cancer anti-apoptotic pathways, stimulation of angiogenesis, and eventually, cancer dissemination (Gonzalez et al., 2018).

Taken together, we can describe essential alterations in the cell physiology that collectively dictate the malignant growth in eight "hallmarks", described previously in influential reviews of Hanahan and Weinberg, which include: sustaining proliferative signaling, evading growth suppressors, resisting cell death, inducing angiogenesis, enabling replicative immortality, inducing angiogenesis, and activating invasion and metastasis (Hanahan et al., 2000), reprogramming of energy metabolism, and evading the immune destruction (Hanahan \& Weinberg, 2011).

Despite the described pre-invasive cancer features, an ability to spread throughout the body is inherently connected with cancer. The abilities of invasion and metastasis of cancer cells can be achieved by the epithelial to mesenchymal transition. Understanding the signaling networks and cross-talks between proteins and microRNAs in that process may enable to develop new treatment strategies in the future and may help to identify novel biomarkers of malignant tumors. This review discusses different signaling networks regulating the epithelial to mesenchymal transition (EMT) process.

\section{REGULATION OF EMT BY PROTEIN SIGNALING PATHWAYS}

Epithelial to mesenchymal transition is a process responsible for tumor metastasis during which epithelial cells gradually transform into mesenchymal-like cells, and lose their epithelial functionality and characteristic molecular features. The first observations of EMT phenotype changes were described with a primitive streak of chick embryos by Elizabeth Hay in the early 1980s (Hay ED., 1995). These findings have opened an entire field of research, which associates EMT's role in both, the physiological and pathological processes. Based on the biological/physiological context, it can be classified into three subtypes: 1) embryogenesis, organogenesis, 2) tissue homeostasis, repairing and fibrosis or 3) cancer progression and metastasis (Pei et al., 2019; Prieto-García et al., 2017; Stone et al., 2016). The transition of epithelial cells into mesenchymal cells follows a common and conserved program with several hallmarks. The key events in EMT are the loss of polarized organization of the epithelial tissue, the dissolution of the epithelial cell-cell junctions, reorganization of the cytoskeletal architecture and changes in cell shape, downregulation of signature epithelial gene expression, and activation of genes that help to define the mesenchymal phenotype, increased cell motility and ability to degrade extracellular matrix (ECM) proteins to enable invasive behavior (Lamouille et al., 2014). Triggering of the EMT process allows cancer cells to disseminate from the primary tumor site, invade adjacent tissues and generate metastasis by colonizing distant sites through the bloodstream and lymphatic system. Once a new metastatic niche has been reached, cells can revert through an opposite process called MET, to re-acquire the initial epithelial characteristics, similar to those in the primary tumor. This step is necessary to allow metastatic colonization (Prieto-García et al., 2017).

The earliest event in EMT is the loss of cell polarity, following dissolution of tight junctions between the cells. It is caused by the loss of epithelial markers, such as the E-cadherin. Downregulation of the E-cadherin level causes breakdown of adherent junctions between cells and loss of cell polarity, leading to acquisition of the mesenchymal phenotype with migratory abilities. This dynamic process can be caused by a complex interplay of several inducers, such as the transforming growth factor (TGF- $\beta$ ) or fibroblast growth factor (FGF), several receptor tyrosine kinases (RTKs), WNT/ $\beta$-catenin, NOTCH, activation of EMT-inducing transcription factors (TFs), microRNAs, epigenetic and post-translational modifications (Ghahhari \& Babashah, 2015; SerranoGomez et al., 2016). These signals regulate the E-cadherin activity and morphogenetic changes. Moreover, loss of the E-cadherin protein expression at the cancer cell surface can be caused by mutations in the E-cadherin gene (Petrova et al., 2016).

Under normal, physiological conditions, the EMT program is activated in epithelial cells through signals that they receive from their neighborhood. In case of carcinoma pathogenesis, these signals are acquired from the recruited cells that form the stroma of tumors, known as the tumor microenvironment. This process is mediated via a series of paracrine cell-cell signaling molecules, among which WNT, TGF- $\beta$ and NOTCH ligands play the main role (Gonzalez \& Medici, 2014).

The WNT signaling pathway (Fig. 1) involves a lot of components, but a major effector is the transcription factor (TF) $\beta$-catenin. WNT signals are transduced across the plasma membrane by the Frizzled and low-density lipoprotein receptor-related protein (LRP) receptors. In the absence of signaling, $\beta$-catenin is phosphorylated by a complex of GSK-3 $\beta$, axin and the tumor suppressor adenomatous polyposis coli (APC), which sequesters $\beta$-catenin in the cytoplasm and marks it for proteasomal degradation. Binding of the WNT ligand to a Frizzled/LRP-5/6 receptor complex causes inhibi-

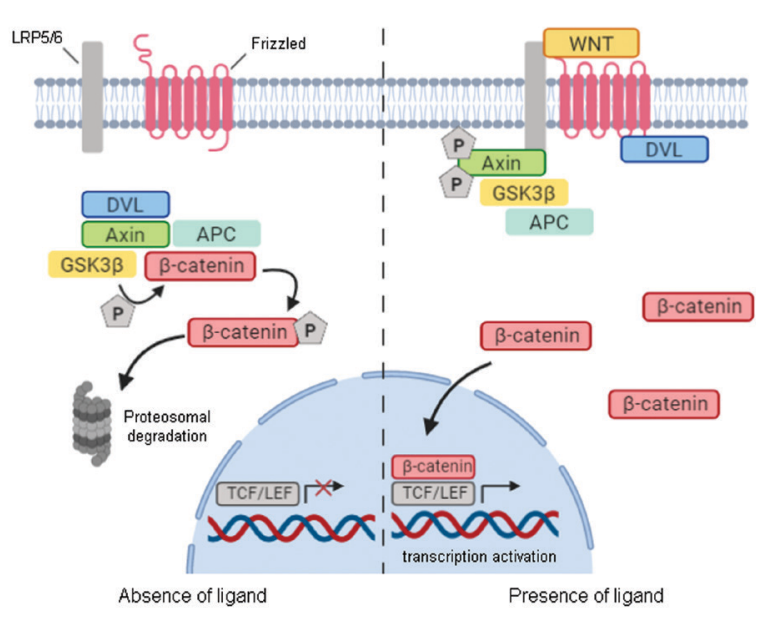

Figure 1. The WNT signaling pathway.

In the absence of the WNT ligand, $\beta$-catenin is phosphorylated by a complex of GSK-3 $\beta$, axin and the tumor suppressor adenomatous polyposis coli (APC), which marks $\beta$-catenin for proteasomal degradation. Binding of the WNT ligand to a Frizzled/LRP-5/6 receptor complex causes inhibition the APC/Axin/GSK-3 $\beta$ destruction complex, which leads to stabilization of $\beta$-catenin and its translocation to the nucleus for transcription activation. 
tion the APC/Axin/ GSK-3 $\beta$ destruction complex, leading to stabilization of $\beta$-catenin and its translocation to the nucleus to activate transcription (Eisenmann, 2005). In the past years the role of WNT signaling has been described in many research papers, mostly in colorectal cancer (Bienz \& Clevers, 2000; Li et al., 2019; Qi et al., 2016; Schwab et al., 2018). Nevertheless, WNT signaling is observed in many other cancers, such as the breast cancer (Green et al., 2013), liver cancer (Takigawa \& Brown, 2008), head and neck squamous cancer (Le et al., 2019), and renal cell carcinoma (Xu et al., 2016; Zhan et al., 2017). Mutations of the WNT signaling components are the major cause of various cancer types. In numerous cancers, WNT signaling is inappropriately active and directly induces SNAIL (SNAI1) and SLUG (SNAI2) transcription factors expression (Behrens, 2005). It was recently shown that upregulation of Axin2 by WNT signaling increases SNAIL levels, leading to EMT (Yook et al., 2006). SNAIL can also activate WNT signaling by binding to $\beta$-catenin, establishing a positive feedback loop for WNT-dependent transcription (Stemmer et al., 2008). SLUG is also stabilized by inhibiting the GSK$3 \beta$ kinase activity and initiates EMT transcriptional programs in different tumor types, including breast cancer cells (Wu et al., 2012). WNT-mediated induction of EMT through SLUG is consistent with other reports of decreased E-cadherin and increased fibronectin levels, after accumulation of $\beta$-catenin in the nucleus (Brabletz et al., 2001). WNT has been also linked to an increased expression of the TWIST transcription factor in mammary epithelial cells (Howe et al., 1906).

The NOTCH signaling pathway consists of $\mathrm{NOTCH}$ receptors, NOTCH ligands and intracellular proteins that function to transmit the NOTCH signal to the nucleus. NOTCH receptors are transmembrane proteins that are composed of an extracellular (NECD), a transmembrane (TM) and an intracellular (NICD) domain. NOTCH ligands are also transmembrane proteins. By binding to the NOTCH NECD they induce proteolytic cleavage and release of NICD, which then enters the cell nucleus to active transcription and modify gene expression (Ehebauer et al., 2006; Kopan \& Ilagan, 2009). NOTCH is a key regulator in the induction of EMT in several different types of carcinoma, such as the breast cancer, lung and squamous cell carcinoma (Natsuizaka et al., 2017; Yuan et al., 2014b). Components of the NOTCH pathway are expressed at high levels in the invasive regions of tumors, which typically express vimentin, a mesenchymal marker, which suggests a crucial role for this pathway in EMT regulation (Saad et al., 2010). SNAIL and SLUG are mediators of NOTCH-mediated repression of E-cadherin and $\beta$-catenin activation (Saad et al., 2010). Interestingly, NOTCH signaling can also cooperate with other pathways, such as TGF- $\beta$, to induce the EMT program. The crosstalk between these pathways occurs via SMADs, which associate with other transcription factors to regulate expression of genes required for acquisition of the mesenchymal fate. For example, silencing components of the NOTCH pathway prevent TGF- $\beta$-induced EMT in keratinocytes (Blokzijl et al., 2003).

The Hedgehog family includes the Sonic Hedgehog $(\mathrm{SHH})$, Desert Hedgehog $(\mathrm{DHH})$ and Indian Hedgehog $(\mathrm{IHH})$ proteins. Hedgehog ligands bind to patched homolog 1/2 (PTCH1/2), which inhibits activity of Smoothened (SMO) in the absence of ligand binding. Activation of PTCH1/2 releases SMO and initiates an intracellular cascade that activates the GLI family transcription factors, which promote transcription of the target genes, such as PTCH, WNT and SNAIL (Gonzalez
\& Medici, 2014). The Hedgehog (HH) pathway signaling can be involved in various stages of carcinogenesis in different tumors. For example, in pancreatic and esophageal cancer, activation of this signaling pathway is found at the early stages of tumor, as well as in the metastatic tumor (Ma et al., 2006). In other tumors, such as the gastric cancer and prostate cancer, activation of the $\mathrm{HH}$ signaling pathway is associated with tissue invasion and increased metastatic potential (Sheng et al., 2004). In context of the EMT regulation, the Farhart's group described that TGF- $\beta$-induced SHH may regulate EMT and tumorigenicity in bladder cancer (Islam et al., 2016). Moreover, they also observed an elevated expression of $\mathrm{N}$-cadherin and $\mathrm{SHH}$ in high grade and stage tumor samples, and conversely, downregulation of these genes was observed in the low grade and stage tumor samples. Recent results also support the hypothesis that $\mathrm{SHH}$ promote EMT by suppressing E-cadherin and enhancing $\mathrm{N}$-cadherin and vimentin (Kitagawa et al., 2019).

The EMT process is mediated by several EMT-related transcription factors (EMT-TFs), such as the SNAIL (SNAI1) and SLUG (SNAI2), TWIST1/2, ZEB1/2. Briefly, they repress genes associated with the epithelial phenotype (such as E-cadherin, etc.) and induce the expression of the mesenchymal genes (such as vimentin, fibronectin) (Lu \& Kang, 2019; Tsai \& Yang, 2013).

Both, SNAIL and SLUG play critical roles in induction of EMT during embryonic development and cancer progression (Aybar et al., 2003). In cancer, their expression leads to a decreased E-cadherin level, enhanced tumor cell invasion and metastatic phenotypes in mouse tumor models and cell line studies, which is associated with poor prognosis in patients with the breast, colorectal, and hepatocellular carcinoma (Blanco et al., 2002; De Craene et al., 2005; Shioiri et al., 2006; Tran et al., 2014; Yook et al., 2006). For example, using multiple genetic breast cancer models with inducible SNAIL transgene or SNAIL conditional knockout, it was demonstrated that the SNAIL expression is required for breast tumor metastasis to the lung (Tran et al., 2014). SNAIL and SLUG can promote breakdown of the extracellular matrix via upregulation of various matrix metalloproteases (MMPs) (Tsai \& Yang, 2013). The TGF- $\beta$, WNT, and NOTCH pathways, as well as growth factors, can activate SNAIL expression depending on the physiological context (Peinado et al., 2007). Moreover, SNAIL and SLUG can also cooperate with other transcription regulators to control gene expression (Lamouille et al., 2014).

Similarly to SNAIL and SLUG, TWIST1/2 belongs to the bHLH (basic helix-loop-helix) transcription family that functions as master regulators of a wide array of developmental and pathological processes. In particular, TWIST-induced suppression of E-cadherin transcription is indirect and is mediated by its transcriptional activation of SLUG, as SLUG knockdown blocks the ability of TWIST to activate EMT in mammary cells (Casas et al., 2011). TWIST expression can be activated by hypoxiainducible factor 1-alpha (HIF-1a) transcription factor under hypoxia conditions to promote EMT and metastasis (Yang et al., 2008). Using xenograft and transgenic tumor models, it has been shown that TWIST1 is essential for tumor cell dissemination and metastasis in breast cancer and squamous cell carcinoma (SCC), although turning off its expression is required for formation of metastasis in distant organs (Tsai et al., 2012; Xu et al., 2017). TWIST overexpression also correlates with cancer invasiveness and metastasis in patients (Lee et al., 2006; Yang et al., 2004). 
Similarly to SNAIL, ZEB1 and ZEB2, two members of the ZEB transcription factor family, directly bind to the E-box elements and repress expression of E-cadherin (Comijn et al., 2001). They also increase the level of mesenchymal proteins, i.e. vimentin and $\mathrm{N}$-cadherin (Bindels et al., 2006; Vandewalle et al., 2005). Expression of the ZEB proteins can be induced by TGF- $\beta$, WNT signaling and other growth factors (Lamouille et al., 2014). It has been shown experimentally in the cancer context, that ZEB1/2 promoted cell migration and invasion in breast cancer and colorectal cancer (Comijn et al., 2001; Vandewalle et al., 2005).

The EMT process is also activated by epigenetic modifications. Epigenetic modifications, such as DNA methylation, histone modification, or nucleosome positioning, alter the structure of chromatin, thereby regulating gene expression. Among epigenetic mechanisms, it is important to highlight modification of the histone tails, global hypomethylation of the genome, and specific hypermethylation of cytosine residues in $\mathrm{CpG}$ islands in the DNA promoter regions, for their role in gene repression and heterochromatin formation (Kouzarides, 2007). Inactivation of a promoter by hypermethylation is common event in several human carcinomas (Tamura et al., 2000.; Wijnhoven et al., 2000; Yoshiura et al., 1995). These modifications cause gene inactivation due to transcriptional silencing, as a consequence of impaired TFs binding to their promoters. On the other hand, different types of modifications in the histone core and tails have been described which can affect the chromatin dynamics and gene expression. Hypermethylation of CDH1 has been reported and associated with EMT and invasiveness (Tamura et al., 2000). Several histone and DNA methyltransferases, and chromatin modifying enzymes related to EMT, have been described. Among them, KDM1A, KDM4B, and KDM6B, causing histone $\mathrm{H} 3$ demethylation at the SNAIL promoter; MMSET, which binds to the TWIST promoter increasing its activation by methylation; LSD1 and SUV39H1, which act by suppressing the CDH1 transcription; SET8 which interacts with TWIST acting both, as a repressor or inducer of gene expression, and also mediates transcriptional activation of WNT target genes; G9A and PRMT5, interacting with both, CDH1 and SNAIL (McDonald et al., 2011; Serrano-Gomez et al., 2016). Taken together, the

\section{EMT}

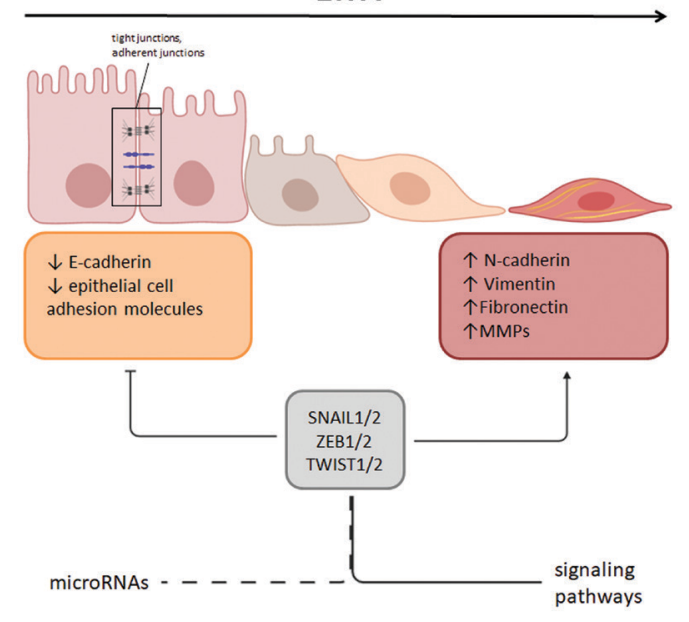

Figure 2. Regulatory network in EMT.

The EMT process can be regulated by many signaling pathways, transcription factors and microRNAs. epigenetic modifications described in cancer suggest that aberrant methylation might be triggered by EMT-related transcription factors or epigenetic regulators associated with them. Moreover, epigenetic modifications may be interdependent and successive, and work in different combinations to induce activation of the EMT program. On the other hand, reversibility of the methylation/demethylation state can mediate the shift between EMT and MET. These findings open new fields of research using methylation inhibitors, as targeting epigenetic regulators of EMT could be a promising therapeutic option. However, these treatments, as some authors have indicated, could also have negative effects, since just as they would reactivate the tumor suppressor gene expression, they could also involuntarily activate oncogenes (Prieto-García et al., 2017).

To summarize, EMT is regulated by different signaling pathways which lead to acquisition of the mesenchymal phenotype by epithelial cancer cell. The EMT regulatory network is schematically described in Fig. 2.

\section{THE ROLE OF MICRORNA IN CANCER}

As mentioned above, EMT is a dynamic process that can be caused by lots of inducers, among which microRNAs seem to be interesting regulators (Serrano-Gomez et al., 2016). MicroRNA (miRNAs) are small non-coding RNAs, with an average length of 22 nucleotides. Most miRNAs are transcribed from DNA sequences into primary miRNAs (pri-miRNAs) and processed into precursor miRNAs (pre-mRNAs), and then into mature miRNAs (Mohr \& Mott, 2015).

There are different types (classes) of small regulatory RNAs: 1) small interfering RNAs (siRNAs), and 2) microRNAs (miRNAs), which are generated by the cleavage of double-stranded (ds) RNA precursor molecules by type III ribonuclease Dicer. Although they share some common biogenesis factors, they are very different in terms of their biological role in the cell (Creugny et al., 2018). MicroRNAs can directly repress target genes by inducing cleavage and degradation of their mRNA targets through a high degree of complementarity matching with their 3' untranslated regions (3'UTR). Lower complementarity causes translational repression (Mohr \& Mott, 2015).

MicroRNAs were found to downregulate gene expression by base-pairing with 3'UTRs of the target messenger RNA (mRNAs) (Reinhart et al, 2000). Each miRNA may regulate many target genes and more than just one miRNA may bind to the same 3' UTR (Ciesla et al., 2011). These discoveries indicated that this class of noncoding RNA molecules may be a new regulatory factor that controls gene expression.

As described previously, cancers are caused by mutations and deregulation of signaling pathways in the cells. The link between microRNA deregulation and cancer was described for the first time by Calin et al.'s research results. They found that the miR15a/16-1 cluster (between exon 2 and exon 5 in the Leu2 gene) is frequently deleted in chronic lymphocytic leukemia (CLL), which suggests that these two microRNAs have a tumor suppressor activity (Calin et al., 2002). Another mechanism leading to an aberrant expression of microRNAs, and thus to cancer progression, is the altered expression and function of enzymes involved in the biogenesis of miRNA, like Drosha and Dicer. Their decreased expression has been found in 39\% of ovarian cancer patients (Merritt et al., 2008). Transcriptional control is another 
important and complex regulation mechanism of miRNA expression. Upregulation of the miR-17/92 cluster modulates an anti-apoptotic action of E2F1, which mediates the MYC proliferative effect (Acunzo et al., 2015; O’Donnell et al., 2005).

Furthermore, some miRNAs may function as oncogenes or tumor suppressors. miRNAs that are overexpressed in cancer may function as oncogenes and promote tumor development by negative regulation of tumor suppressor genes and genes that control cell differentiation and apoptosis. Underexpressed miRNAs may function as suppressor genes and they inhibit cancer development by regulation of oncogenes and genes that control cell differentiation and apoptosis (Shenouda \& Alahari, 2009; Zhang et al., 2007).

\section{MICRORNAS AS THE KEY REGULATORS OF EMT}

miRNAs may act as regulators of both, EMT facilitating tumor dissemination and its reverse process MET, which promotes metastatic colonization (Tsai \& Yang, 2013). Interestingly, attenuation of global biogenesis of miRNAs by miR-103/107 targeting DICER was demonstrated to induce EMT and metastasis in breast cancer (Martello et al., 2010). Global miRNA downregulation was shown previously to be a common trait in tumors (Lu et al., 2005), whereas poor prognosis of different cancer types is associated with a diminished expression of miRNA processing factors (Sandberg et al., 2008).

miRNAs regulate EMT mostly by targeting the main transcription factors involved in this process, such as SNAIL, SLUG, TWIST, ZEB1 and ZEB2. Nevertheless, those factors may also function as regulators of the miRNAs level. Another type of miRNA's role is regulation of the cellular contact, adhesion and cytoskeletal proteins, which induces changes in the epithelial to mesenchymal phenotype (Expósito-Villén et al., 2018). Examples of those interactions are described below.

Expression of SNAIL transcription factor may be regulated by different miRNAs with implications in the EMT process. The SNAIL 3'UTR acts as a sponge for multiple metastasis-related miRNAs, such as miR-153, miR-199a-5p, miR-203, miR-204, miR-22, and miR-34c (Li et al., 2015). The miR-30 family is one of the most widely described SNAIL regulators in several tumor types, including non-small cell lung carcinoma (Kumarswamy et al., 2012) or breast cancer (Xiao et al., 2018), which leads to EMT regulation in epithelial tumors, or is responsible for non-canonical mechanism of SNAIL effects in the mesenchymal tumors, including rhabdomyosarcoma (Skrzypek et al., 2018).

miRNAs can also regulate the SLUG level, such as for example miR-203 in glioblastoma (Liao et al., 2015) or breast cancer (Zhang et al., 2011).

The TWIST1 level is also affected by several miRNAs, including miR-26b-5p in hepatocellular carcinoma (Wang et al., 2016), miR-106b in endometrial cancer (Dong et al., 2014), miR-361-5p in glioma cells (Zhang et al., 2017) or miR-720 (Li et al., 2014b) in breast cancer or miR-300 in gastric cancer (Yu et al., 2014).

ZEB1 and ZEB2 expression during EMT is regulated by the largest number of miRNAs. For example, ZEB1 it is targeted by miR-33 in adenocarcinoma (QU et al., 2015), miR-128 in esophageal squamous cell cancer, and miR-200 (Zhao et al., 2018) in breast cancer (Bai et al., 2014).

Some of the crucial regulators of the ZEB2 level are members of the miR-200 family. They were shown as regulators in different tumor types, including glioma ( $\mathrm{Li}$ et al., 2016), lung cancer (Jiao et al., 2016), and gastric carcinoma (Li et al., 2014a). ZEB2 is targeted in lung cancer by miR-132 (You et al., 2014) and miR-154 (Lin et al., 2016), or in colorectal cancer by miR-132 (Zheng et al., 2014).

Nevertheless, besides examples of single miRNAs targeting different transcription factors in EMT, the most interesting are cross-talks between distinct transcription factors and miRNAs. One miRNA may have plenty of targets in different genes to regulate EMT. Therefore, transcription factors may be co-regulated by one miRNA. miR-200 was shown to regulate both SLUG and ZEB1 (Zhang et al., 2014), as well as the ZEB1 and SNAIL levels (Díaz-López et al., 2015) (Shan et al., 2013), miR-218 affects the level of SLUG and ZEB2 (Shi et al., 2017), and miR-129 coregulates TWIST and SNAIL (Yu et al., 2015b). These types of regulation demonstrate key roles of miRNAs in regulation of the EMT process.

On the other hand, there are also examples of miRNAs regulated by more than one EMT-associated transcription factor. An interesting example is miR-375, which is regulated by direct binding of SNAIL (Xu et al., 2014b) and ZEB1 to its promoter (Selth et al., 2017). During EMT, both SNAIL and ZEB1 engage miR-200f epigenetic and transcriptional regulation (Díaz-López et al., 2015).

The EMT-related transcription factors may be involved in cross-talks based on their regulation of miRNA expression, with implications in epithelial tumor progression and the role of EMT in this process. SNAIL and SLUG repress miR-101 expression, which is essential for malignant phenotypes and EMT induction of squamous cell carcinoma of the oral tongue (Zheng et al., 2015), whereas miR-101 acts as a tumor suppressor by direct ZEB1 targeting in various cancers, including colorectal cancer (Xiong et al., 2018), so there are cross-talks between EMT-related transcription factors via miRNAs.

Double negative or positive feedback loops between miRNAs and transcription factors are also described in the literature. Those loops are made of two interactions, so that the EMT-related transcription factors and miRNAs regulate each other. That regulation may either induce or repress expression. The mechanism may involve direct binding of transcription factors to miRNA promoters or direct binding of miRNAs to 3'UTR regions of transcription factors or can be indirect through mediators. Below, several examples of that regulation are described. Positive feed-forward regulatory loop was described for miR-373 that induces the TWIST level, and subsequently TWIST induces miR-373 expression by binding to its promoter (Chen et al., 2015). miR-1 and miR-200 can regulate SLUG, and SLUG is also a direct repressor of their action, which forms an interesting negative regulatory loop (Liu et al., 2013a). EMT has been also shown to be regulated by the miR-34 and SNAIL double negative feedback loop. miR-34 binds to 3'UTR region of SNAIL and thereby represses its expression, whereas SNAIL binds to miR-34 promoter to diminish its level (Siemens et al., 2011). That loop regulates EMT in human colon and breast cancer (Habn et al., 2013). That mechanism is dependent on the p53 function. Without the wild-type p53 function, decreased levels of miR-34 result in a SNAIL-dependent EMT (Kim et al., 2011), whereas activation of p53 down-regulates the EMT-inducing transcription factor SNAIL via induction of the miR-34 genes (Siemens et al., 2011).

An interesting negative feedback loop also exists between miR-203 and SLUG (Ding et al., 2013), and be- 
tween miR-203 and SNAIL that acts as a regulator of the miR-200 expression and its targets, ZEB1 and ZEB2 (Moes et al., 2012).

Certain miRNAs may induce EMT because they act as additional blockers of E-cadherin, besides SNAIL and SLUG. miR-221, which is regulated by SLUG, suppresses the E-cadherin level and thereby promotes breast cancer metastasis (Pan et al., 2016). In breast cancer, miR210 suppresses E-cadherin expression by targeting the open reading frame region of E-cadherin mRNA (Tang et al., 2018). Another example is pro-metastatic miR-9 - it also targets mRNA encoding E-cadherin (Ma et al., 2010). miR-10b and miR-214 also directly regulate E-cadherin by targeting its 3’UTR (Zhang et al., 2015) (Liu et al., 2018). Moreover, multiple miRNAs regulate E-cadherin level indirectly, such as for example members of the miR-200 family (Korpal et al., 2008).

MiRNAs acting as EMT inducers may not be equal functionally. From the set of EMT-associated miRNAs, the most commonly upregulated miRNAs, miR-22 and miR-100, and the most significantly downregulated miRNAs, are capable of inducing EMT in mammary epithelial cells (Martello et al., 2010). MiRNAs inducing EMT may have different functions which depend on their specific target genes.

MiRNAs may regulate not only the epithelial, but also mesenchymal markers, such as vimentin. MiR-22 was shown to affect its level ( $\mathrm{Xu}$ et al., 2018). What is more, miR-199a modulates the N-cadherin level (Suzuki et al., 2014), whereas miR-27a directly regulates vascular endothelial (VE)-cadherin (Zhao et al., 2016).

The RhoA protein plays a crucial role in re-organization of the actin cytoskeleton and its level is affected by several miRNAs, including miR-122 (Wang et al., 2014), miR-24 (Papadimitriou et al., 2012), and miR-1291 (Xu et al., 2017a).

miR-29b inhibits metastasis by regulating the level of proteins involved in epithelial plasticity and differentiation in breast cancer, such as TGFB1, ITGA6, and ITGB1. Moreover, miR-29b also affects several pro-metastatic proteins levels, such as VEGF, MMP2, MMP9 or PDGF (Chou et al., 2013).

MiRNAs may be also regulated by long non-coding RNAs in the EMT process. In colorectal cancer, long noncoding RNA XIST modulates EMT by competing for miR-200b-3p to modulate the ZEB1 expression (Chen et al., 2017a). Another example is long non-coding RNA UICLM which promotes colorectal cancer liver metastasis by acting as a competitive endogenous RNA for microRNA-215 to regulate the ZEB2 level (Chen et al., 2017b). What is more, the SLUG level was demonstrated to be regulated by $\operatorname{lncRNA}$ UCA1 by interaction with miR-203 (Xiao et al., 2017). Another interesting example is lncRNA CAR10, which directly binds two miRNAs: miR-30 and miR-203, and in that way regulates the level of both, SNAIL and SLUG in EMT (Ge et al., 2019). MALAT1 lncRNA acts as a sponge for miR126-5p that directly targets TWIST, SLUG and VEGF in colorectal cancer, which regulates both metastasis and angiogenesis (Sun et al., 2019). An increasing number of research papers shows several lncRNAs involved in regulation of EMT by modification of the TGF- $\beta$ (Yuan et al., 2014a) or WNT pathways (Jiang et al., 2018). Usually, lncRNAs act as sponges for miRNAs involved in EMT. Examples of interactions between lncRNAs, miRNAs and EMT-related factors are shown in Fig. 3.

MiRNAs may be also affected by epigenetic modifications. miRNAs' promoters may be hypermethylated or demethylated, which affects their expression. This

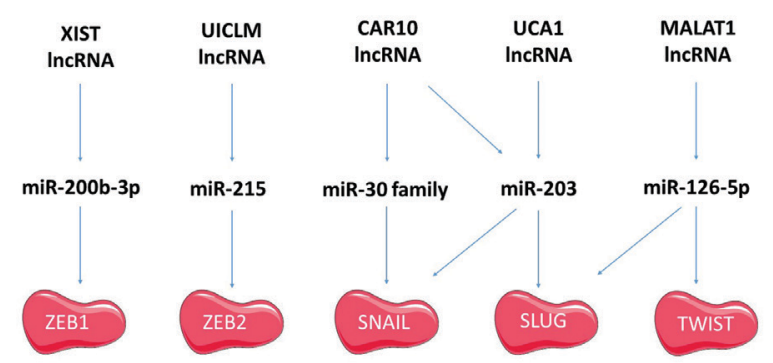

Figure 3. Selected examples of crosstalks between IncRNAs, miRNAs and EMT-related factors.

mechanism was described in different cell types for several miRNAs regulating EMT, such as for example miR200 (Pieraccioli et al., 2013) and miR-203 (Taube et al., 2013). On the other hand, an opposite mechanism also regulates EMT. Impaired EMT process may be a result of targeting epigenetic modulators, such as DNMT by miR-152 (Yu et al., 2015a).

MiRNAs associated with EMT-related transcription factors in epithelial tumors may also play crucial roles in progression of the mesenchymal tumors. An interesting example is regulation of rhabdomyosarcoma growth - in that tumor, SNAIL regulates expression of myogenic associated miRNAs, such as miR-1, miR-206, and miR-378, to affect tumor growth involving other mechanisms than EMT (Skrzypek et al., 2018). miR-1 was previously shown to inhibit EMT via SLUG-dependent and via SLUG-independent mechanisms (Liu et al., 2013b). Moreover, tumor suppressor miR-1 restrains the epithelial-mesenchymal transition and metastasis of colorectal carcinoma via the MAPK and PI3K/AKT pathways (Xu et al., 2014a). miR-206 is a regulator of SLUG and MET in different tumor types. For example, in epithelial tumors, miR-206 regulates EMT in human lung adenocarcinoma cells partly by targeting MET (Chen et al., 2016). That mechanism of regulation is also important in metastasis of mesenchymal tumors, such as rhabdomyosarcoma (Yan et al., 2009; Szewczyk et al., 2017). Those results suggest that miRNAs identified to regulate EMT in epithelial tumors may be also significant in metastasis of the mesenchymal tumor types.

\section{MICRORNAS AS BIOMARKERS AND THERAPEUTICS IN CANCER}

The main cause of death in cancer patients is metastasis of tumor cells to distant organs from the primary epithelial tumor. For this reason, understanding the cellular mechanisms that lead to metastasis is critical in the fight against cancer.

miRNAs may have clinical relevance as biomarkers. These biomarkers can be used to indicate presence of a given cancer and predict its stage, progression or drug efficiency (Armand-Labit \& Pradines, 2017; Ciesla et al., 2011).

The use of circulating miRNAs as biomarkers in different cancer types is a rapidly developing field. Tumor cells can release miRNAs that can be stabilized by incorporation into microvesicles which have shown stability in the circulation, following multiple freeze-thaw cycles and prolonged exposure to room temperature. miRNAs have also shown stability in other body fluids, but most of the studies focused on serum miRNAs as biomarkers. Moreover, the circulating miRNAs show constant level in the blood of healthy individuals. In cancer patients, most of 
Table 1. Examples of clinical trials with microRNA as clinical biomarkers in cancer (clinicaltrials.gov).

\begin{tabular}{|c|c|c|c|c|}
\hline miRNA gene & Trial & $\begin{array}{l}\text { Clinical trial num- } \\
\text { ber; phase status }\end{array}$ & Cancer type investigated & References \\
\hline $\begin{array}{l}\operatorname{miR}-31-3 p \\
\text { miR-31-5p; }\end{array}$ & $\begin{array}{l}\text { Expression of microRNA biomarkers as pro- } \\
\text { gnostic of patient outcomes or predictive of } \\
\text { the benefit from anti-EGFR therapy in stage } \\
\text { III colon cancer }\end{array}$ & $\begin{array}{l}\text { NCT03362684; } \\
\text { phase } 3 \text { (comple- } \\
\text { ted) }\end{array}$ & Colorectal cancer (CRC) & (Taieb et al., 2014) \\
\hline $\begin{array}{l}\text { Numerous } \\
\text { miRNAs }\end{array}$ & $\begin{array}{l}\text { MicroRNA Profile in early-stage cervical } \\
\text { cancer }\end{array}$ & $\begin{array}{l}\text { NCT04087785 } \\
\text { (completed) }\end{array}$ & Cervical cancer & - \\
\hline $\begin{array}{l}\text { Numerous } \\
\text { miRNAs }\end{array}$ & $\begin{array}{l}\text { MicroRNA profile of early cardiotoxicity in } \\
\text { breast cancer patients treated with anthra- } \\
\text { cyclines }\end{array}$ & $\begin{array}{l}\text { NCT02065908 } \\
\text { (completed) }\end{array}$ & Breast cancer & - \\
\hline miR-10b & $\begin{array}{l}\text { Expression levels as biomarkers of tumor } \\
\text { grade, survival and genetic variation }\end{array}$ & $\begin{array}{l}\text { NCT01849952; } \\
\text { (recruiting) }\end{array}$ & Glioma & - \\
\hline miR-29a & $\begin{array}{l}\text { Exploration of prognostic value of miR-29b } \\
\text { in tissue, blood and saliva }\end{array}$ & NCT02009852 & $\begin{array}{l}\text { Oral Squamous cell car- } \\
\text { cinoma }\end{array}$ & - \\
\hline $\begin{array}{l}\text { Numerous } \\
\text { miRNAs }\end{array}$ & $\begin{array}{l}\text { Identifying biomarkers for patient stratifica- } \\
\text { tion in tissue samples }\end{array}$ & $\begin{array}{l}\text { NCT01828918 } \\
\text { (unknown) }\end{array}$ & Colorectal cancer & - \\
\hline $\begin{array}{l}\text { Numerous } \\
\text { miRNAs }\end{array}$ & $\begin{array}{l}\text { Analysis of microRNA expression in basal cell } \\
\text { carcinoma }\end{array}$ & $\begin{array}{l}\text { NCT01498250 } \\
\text { (completed) }\end{array}$ & Basal cell carcinoma & - \\
\hline miR-29 family & $\begin{array}{l}\text { Investigate the role of microRNA in Twist1- } \\
\text {-mediated cancer metastasis }\end{array}$ & $\begin{array}{l}\text { NCT01927354; } \\
\text { (unknown) }\end{array}$ & $\begin{array}{l}\text { Head and neck squamous } \\
\text { cell carcinoma }\end{array}$ & - \\
\hline $\begin{array}{l}\text { Circulating } \\
\text { secret miRNAs }\end{array}$ & Biomarker of response to treatment & $\begin{array}{l}\text { NCT01391351; } \\
\text { (completed) }\end{array}$ & Breast cancer & - \\
\hline $\begin{array}{l}\text { Numerous } \\
\text { miRNAs }\end{array}$ & $\begin{array}{l}\text { MicroRNAs Expression profiles in initiation, } \\
\text { progression and treatment response }\end{array}$ & $\begin{array}{l}\text { NCT01108159; } \\
\text { (completed) }\end{array}$ & Hematologic cancer & - \\
\hline
\end{tabular}

the circulating miRNAs are directly delivered from the tumor tissue (Armand-Labit and Pradines, 2017). On the other hand, circulating miRNAs can occur as a result of treatment, diet or other factors, which increases the noise level in these assays (Hayes et al., 2014). The most current clinical trials for the use of miRNAs as biomarkers for cancer prognosis and drug efficacy studies were described in Table 1.

Deregulation of miRNA expression plays a key role in cancer development. Modulating of miRNA levels or restoring their function may be a new strategy in the cancer treatment. There are two ways to modulate the level of a particular miRNA: restoration of tumor suppressor miRNA by a straightforward transfection of synthetic mimics or transduction of cells with vectors expressing miRNAs (Miroshnichenko \& Patutina, 2019). On the other hand, new technologies have been developed to inhibit functions of oncogenic miRNAs. Such compounds may target the miRNA sequence or interrupt the miRNA regulatory activity through interaction with their mRNA targets (Miroshnichenko \& Patutina, 2019). Modulation of the miRNAs' level may be used to directly target tumor cells or it may also enhance other therapies, which has been shown in small cell lung cancer for miR100 that regulated chemo-resistant properties of cancer cells (Xiao et al., 2014). Another example is the epigenetic silencing of miR-199b-5p in a chemoresistant ovarian cancer (Liu et al., 2014).

The miRNA treatment and therapies are challenged by several obstacles. One is associated with off-target effects, which can lead to unwanted responses in tissues other than the intended ones (Broderick \& Zamore, 2011; Chakraborty et al., 2017). Another obstacle is the successful delivery of the therapeutic agent to the target tissues. Therapeutics must overcome problems associated with oligonucleotides, such as degradation by nucleases, renal clearance, failure to cross the capillary endothelium, ineffective endocytosis by target cells, or ineffective endosome release (Kim \& Rossi, 2007). Different de- livery systems are used for better bioavailability, including PEGylated liposomes, lipidoids, and biodegradable polymers. Vesicles with diameters between 50 and 500 nm have been used to deliver therapeutic miRNAs and siRNAs. These vesicles prevent the drugs from being filtered by the kidneys and improve intracellular delivery (Broderick \& Zamore, 2011).

Furthermore, while local delivery into the eye or skin has been shown to improve bioavailability in the targeted sites, systemically delivered miRNA formulations and RNA-based miRNA targeting agents might be negatively impacted by the host immune system, since macrophages and monocytes can remove complexed RNAs from the extracellular spaces (Broderick \& Zamore, 2011). For instance, 21 base pair or longer dsRNAs can lead to a sequence-independent interferon response (Pai et al., 2006). An additional challenge is represented by the release of RNA-based therapeutics formulated in complexes larger than $5 \mathrm{~nm}$ in diameter, from the blood to the target tissue through the capillary endothelium (Whitehead et al., 2009). Another challenge is the safety evaluation of miRNA-based therapeutics, such as the mentioned above potential immune response against the delivery system, toxicity caused by the chemical modification or unexpected off-target effects that are likely to occur, because each miRNA can affect hundreds of target genes. Another obstacle for anti-miR therapeutics is the complexity of the assessment of anti-miR efficacy. This is because anti-miR treatment may not always reduce the miRNA expression levels. High throughput profiling of global mRNA and protein changes in samples could provide more comprehensive information regarding the specificity and effectiveness of a particular anti-miR treatment (Chakraborty et al., 2017).

Clinical trials were established for miRNA mimics (to overexpress the transcript), as well as repressors (to silence the transcript function). The first recently completed phase I trial based on a new technology termed "TargomiR" exhibited encouraging results in patients 
Table 2. Interventional clinical trials for microRNAs as therapeutic target (clinicaltrials.gov).

\begin{tabular}{lll}
\hline miRNA gene; drug name & $\begin{array}{l}\text { Clinical trial number; } \\
\text { Phase status }\end{array}$ & Cancer type investigated \\
\hline miRNA-34a; MRX34 & $\begin{array}{l}\text { NCT01829971; } \\
\text { Phase I (terminated) }\end{array}$ & Hepatocellular carcinoma (HCC) \\
\hline $\begin{array}{l}\text { NCT02369198; } \\
\text { Targ-16; }\end{array}$ & Phase I (completed) & $\begin{array}{l}\text { Malignant pleural mesothelioma } \\
\text { non-small cell lung cancer (NSCLC) }\end{array}$ \\
\hline
\end{tabular}

with malignant pleural mesothelioma or non-small cell lung cancer. Briefly, TargomiR delivery vehicles contain a miRNA mimic, the drug delivery vehicle - EDVs that are nonliving bacterial minicells (nanoparticles), and a targeting moiety (i.e. a specific antibody that recognizes a protein on a target cells). In that first human trial of TargomiR drug, the miRNA mimic for miR-16 and a bispecific antibody to the epidermal growth factor receptor (EGFR) were used (Reid et al., 2013; van Zandwijk et al., 2017). Other clinical studies of miRNAs are described in Table 2. They give hope for an interesting future for miRNA drugs in cancer.

\section{CONCLUSIONS AND PERSPECTIVES}

The level of different proteins regulating EMT may be affected by non-coding RNAs, such as miRNAs. MiRNAs may regulate EMT-related transcription factors by direct binding to the 3'UTR region of their mRNA or indirectly, as well as those transcription factors may regulate their level. Sometimes there are crosstalks between several miRNAs and more than one transcription factor, as well as feedback loops are described in the literature. MiRNAs regulate not only the EMT-related transcription factors, but they also affect the level of epithelial and mesenchymal markers and proteins associated with reorganization of the cytoskeleton. Long non-coding RNAs usually act as sponges for miRNAs involved in EMT regulation. Understanding of the complicated signaling networks regulating EMT may help to identify novel biomarkers or develop new treatment strategies. Some of the miRNAs described above have already been enrolled in clinical trials as miRNA based therapeutics. For example miR-34 and miR-29 based therapeutics are under investigation in phase 1 clinical trials (Hanna et al., 2019). In the future, there are perspectives for more miRNAs to be used in the therapeutic approaches.

\section{REFERENCES}

Acunzo M, Romano G, Wernicke D, Croce CM (2015) MicroRNA and cancer - A brief overview. Adv. Biol. Regul. 57: 1-9. http://doi. org/10.1016/j.jbior.2014.09.013

Armand-Labit V, Pradines A (2017) Circulating cell-free microRNAs as clinical cancer biomarkers. Biomol. Concepts 8: 61-81. http://doi. org/10.1515/bmc-2017-0002

Aybar MJ, Nieto MA, Mayor R (2003) Snail precedes Slug in the genetic cascade required for the specification and migration of the Xenopus neural crest. Development 130: 483-494. http://doi.org/10.1242/ dev.00238

Bai W-D, Ye X-M, Zhang M-Y, Zhu H-Y, Xi W-J, Huang X, Zhao J, Gu B, Zheng G-X, Jia LT (2014) MiR-200c suppresses TGF- $\beta$ signaling and counteracts trastuzumab resistance and metastasis by targeting ZNF217 and ZEB1 in breast cancer. Int. J. Cancer 135: 1356-1368. http://doi.org/10.1002/ijc.28782

Beg MS, Brenner AJ, Sachdev J, Borad M, Kang YK, Stoudemire J, Smith S, Bader AG, Kim S, Hong DS (2017) Phase I study of MRX34, a liposomal miR-34a mimic, administered twice weekly in patients with advanced solid tumors. Invest. New Drugs 35: 180-188. http://doi.org/10.1007/s10637-016-0407-y
Behrens J (2005) The role of the Wnt signalling pathway in colorectal tumorigenesis. Biochem. Soc. Trans. 33: 672-675. https://doi. org/10.1042/BST0330672

Bienz M, and Clevers H (2000) Linking colorectal cancer to wnt signaling. Cell 13: 311-320. https://doi.org/10.1016/s00928674(00)00122-7

Bindels S, Mestdagt M, Vandewalle C, Jacobs N, Volders L, Noël A, Roy F Van, Berx G, Foidart JM, Gilles C (2006) Regulation of vimentin by SIP1 in human epithelial breast tumor cells. Oncogene 25: 4975-4985. http://doi.org/10.1038/sj.onc.1209511

Blanco MJ, Moreno-Bueno G, Sarrio D, Locascio A, Cano A, Palacios J, Nieto A (2002) Correlation of Snail expression with histological grade and lymph node status in breast carcinomas. Oncogene 21: 3241-3246. http://doi.org/10.1038/sj/onc/1205416

Blokzijl A, Dahlqvist C, Reissmann E, Falk A, Moliner A, Lendahl U, Ibáñez CF (2003) Cross-talk between the Notch and TGF- $\beta$ signaling pathways mediated by interaction of the Notch intracellular domain with Smad3. J. Cell Biol. 163: 723-728. http://doi. org/10.1083/jcb.200305112

Brabletz T, Jung A, Reu S, Porzner M, Hlubek F, Kunz-Schughart LA, Knuechel R, Kirchner T, Weinberg RA (2001) Variable-catenin expression in colorectal cancers indicates tumor progression driven by the tumor environment. Proc. Natl. Acad. Sci. U. S. A. 98: 1035610361. https://doi.org/10.1073/pnas.171610498

Broderick JA, Zamore PD (2011) MicroRNA therapeutics. Gene Ther. 18: 1104-1110. http://doi.org/10.1038/gt.2011.50

Calin GA, Dumitru CD, Shimizu M, Bichi R, Zupo S, Noch E, Aldler H, Rattan S, Keating M, Rai K, Rassenti L, Kipps T, Negrini M, Bullrich F, Croce CM (2002) Frequent deletions and down-regulation of micro- RNA genes miR15 and miR16 at $13 \mathrm{q} 14$ in chronic lymphocytic leukemia. Proc. Natl. Acad. Sci. U. S. A. 99: 15524 15529. http://doi.org/10.1073/pnas.242606799

Casas E, Kim J, Bendesky A, Ohno-Machado L, Wolfe CJ, Yang J (2011) Snail2 is an essential mediator of twist1-induced epithelial mesenchymal transition and metastasis. Cancer Res. 71: 245-254. http://doi.org/10.1158/0008-5472.CAN-10-2330

Chakraborty C, Sharma AR, Sharma G, Doss CGP, Lee SS (2017) Therapeutic miRNA and siRNA: Moving from bench to clinic as next generation medicine. Mol. Ther. - Nucleic Acids 8: 132-143. http://doi.org/10.1016/j.omtn.2017.06.005

Chen D, Dang B-L, Huang J, Chen M, Wu D, Xu M-L, Li R, Yan G-R (2015) MiR-373 drives the epithelial-to-mesenchymal transition and metastasis via the miR-373-TXNIP-HIF1 $\alpha$-TWIST signaling axis in breast cancer. Oncotarget 6: 32701-32712. http://doi. org/10.18632/oncotarget.4702

Chen D, Chen L, Lu Y, Zhang D, Zeng Z, Pan Z, Huang P, Wang F, Li Y, Ju H, Xu RH (2017a) Long noncoding RNA XIST expedites metastasis and modulates epithelial-mesenchymal transition in colorectal cancer. Cell Death Dis. 8: e3011-e3011. http://doi. org/10.1038/cddis.2017.421

Chen D, Lu Y, Zhang J, Wei X, Wang F, Zeng Z, Pan Z, Yuan Y, Wang F, Pelicano H, Chiao PJ, Huang P, Xie D, Li YH, Ju HQ, Xu RH (2017) Long non-coding RNA UICLM promotes colorectal cancer liver metastasis by acting as a ceRNA for microRNA-215 to regulate ZEB2 expression. Theranostics 7: 4836-4849. http://doi. org/10.7150/thno.20942

Chen Q, Jiao D, Wang J, Hu H, Tang X, Chen J, Mou H, Lu W (2016) miR-206 regulates cisplatin resistance and EMT in human lung adenocarcinoma cells partly by targeting MET. Oncotarget 7: 24510-24526. http://doi.org/10.18632/oncotarget.8229

Chou J, Lin JH, Brenot A, Kim J, Provot S, Werb Z (2013) GATA3 suppresses metastasis and modulates the tumour microenvironment by regulating microRNA-29b expression. Nat. Cell Biol. 15: 201-213. http://doi.org/10.1038/ncb2672

Ciesla M, Skrzypek K, Kozakowska M, Loboda A, Jozkowicz A, Dulak J (2011) MicroRNAs as biomarkers of disease onset. Anal. Bioanal. Chem. 401: 2051-2061. http://doi.org/10.1007/s00216-011-5001-8

Comijn J, Berx G, Vermassen P, Verschueren K, Van Grunsven L, Bruyneel E, Mareel M, Huylebroeck D, and Van Roy F (2001) The two-handed $\mathrm{E}$ box binding zinc finger protein SIP1 downregulates e-cadherin and induces invasion. Mol. Cell. 7: 1267-1278. https:// doi.org/10.1016/s1097-2765(01)00260-x 
Cooper G (2000) The Development and Causes of Cancer. In The Cell: A Molecular Approach. Sinauer Associates

De Craene B, van Roy F, Berx G (2005) Unraveling signalling cascades for the Snail family of transcription factors. Cell. Signal. 17: 535-547. http://doi.org/10.1016/j.cellsig.2004.10.011

Creugny A, Fender A, Pfeffer S (2018) Regulation of primary microRNA processing. FEBS Lett. 592: 1980-1996. http://doi. org $/ 10.1002 / 1873-3468.13067$

Díaz-López A, Díaz-Martín J, Moreno-Bueno G, Cuevas EP, Santos V, Olmeda D, Portillo F, Palacios J, Cano A (2015) Zeb1 and Snail1 engage miR-200f transcriptional and epigenetic regulation during EMT. Int. J. Cancer 136: E62-E73. http://doi.org/10.1002/ijc.29177

Ding X, Park SI, McCauley LK, Wang C-Y (2013) Signaling between Transforming growth factor $\beta$ (TGF- $\beta$ ) and transcription factor SNAI2 represses expression of microRNA miR-203 to promote epithelial-mesenchymal transition and tumor metastasis. J. Biol. Chem. 288: 10241-10253. http://doi.org/10.1074/jbc.M112.443655

Dong P, Kaneuchi M, Watari H, Sudo S, Sakuragi N (2014) MicroRNA-106b modulates epithelial-mesenchymal transition by targeting TWIST1 in invasive endometrial cancer cell lines. Mol. Carcinog. 53: 349-359. http://doi.org/10.1002/mc.21983

Ehebauer M, Hayward P, Martinez-Arias A (2006) Notch signaling pathway. Sci. STKE 2006: cm7. http://doi.org/10.1126/ stke.3642006 $\mathrm{cm} 7$

Eisenmann DM (2005) Wnt signaling. WormBook 25: 1-17. http://doi. org/10.1895/wormbook.1.7.1

Expósito-Villén A, E Aránega A, Franco D (2018) Functional role of non-coding RNAs during epithelial-to-mesenchymal transition. NonCoding RNA 4: 14. http://doi.org/10.3390/ncrna4020014

Fouad YA, Aanei C (2017) Revisiting the hallmarks of cancer. 7: 10161036. https://www.ncbi.nlm.nih.gov/pmc/articles/PMC5446472/

Ghahhari NM, Babashah S (2015) Interplay between microRNAs and WNT/ $\beta$-catenin signalling pathway regulates epithelial-mesenchymal transition in cancer. Eur. J. Cancer 51: 1638-1649. http://doi. org/10.1016/j.ejca.2015.04.021

Gonzalez DM, and Medici D (2014) Signaling mechanisms of the epithelial-mesenchymal transition. Sci. Signal. 7: re8. http://doi. org/10.1126/scisignal.2005189

Gonzalez H, Hagerling C, Werb Z (2018) Roles of the immune system in cancer: from tumor initiation to metastatic progression. Genes Dev 32: 1267-1284. http://doi.org/10.1101/gad.314617.118.tissue

Green JL, La J, Yum KW, Desai P, Rodewald LW, Zhang X, Leblanc M, Nusse R, Lewis MT, Wahl GM (2013) Paracrine Wnt signaling both promotes and inhibits human breast tumor growth. Proc. Natl. Acad. Sci. U. S. A. 110: 6991-6996. http://doi.org/10.1073/ pnas. 1303671110

Hahn S, Jackstadt R, Siemens H, Hünten S, Hermeking H (2013) SNAIL and miR-34a feed-forward regulation of ZNF281/ZBP99 promotes epithelial-mesenchymal transition. EMBO J. 32: 30793095. http://doi.org/10.1038/emboj.2013.236

Hanahan D, Weinberg RA (2011) Hallmarks of cancer: the next generation. Cell 144: 646-674: http://doi.org/10.1016/i.cell.2011.02.013

Hanahan D, Weinberg RA, Francisco S (2000) The hallmarks of cancer. Cell 100: 57-70. 10.1016/s0092-8674(00)81683-9

Hanna J, Hossain GS, Kocerha J (2019) The potential for microRNA therapeutics and clinical research. Front. Genet. 10: 478. http://doi. org/10.3389/fgene.2019.00478

Hay ED (1995) An overview of epithelio-mesenchymal transformation. Acta Anat 154: 8-20. https://doi.org/10.1159/000147748

Hayes J, Peruzzi PP, Lawler S (2014) MicroRNAs in cancer: Biomarkers, functions and therapy. Trends Mol. Med. 20: 460-469. http://doi. org/10.1016/j.molmed.2014.06.005

Howe LR, Watanabe O, Leonard J, Brown AMC (2003) Twist is upregulated in response to Wnt1 and inhibits mouse mammary cell differentiation. Cancer Res. 63: 1906-1913

Islam SS, Mokhtari RB, Noman AS, Uddin M, Rahman MZ, Azadi MA, Zlotta A, van der Kwast T, Yeger H, Farhat WA (2016) Sonic hedgehog (Shh) signaling promotes tumorigenicity and stemness via activation of epithelial-to-mesenchymal transition (EMT) in bladder cancer. Mol. Carcinog. 55: 537-551. http://doi.org/10.1002/ mc. 22300

Jiang Z, Jiang C, Fang J (2018) Up-regulated lnc-SNHG1 contributes to osteosarcoma progression through sequestration of miR-577 and activation of WNT2B/Wnt/B-catenin pathway. Biochem. Biophys. Res. Commun. 495: 238-245. http://doi.org/10.1016/j.bbrc.2017.11.012

Jiao A, Sui M, Zhang L, Sun P, Geng D, Zhang W, Wang X, Li J (2016) MicroRNA-200c inhibits the metastasis of non-small cell lung cancer cells by targeting ZEB2, an epithelial-mesenchymal transition regulator. Mol. Med. Rep. 13: 3349-3355. http://doi. org $/ 10.3892 / \mathrm{mmr} .2016 .4901$

Kim DH, Rossi JJ (2007) Strategies for silencing human disease using RNA interference. Nat. Rev. Genet. 8: 173-184. http://doi. org $/ 10.1038 /$ nrg2006

Kim NH, Kim HS, Li X-Y, Lee I, Choi H-S, Kang SE, Cha SY, Ryu JK, Yoon D, Fearon ER, Rowe RG, Lee S, Maher CA, Weiss SJ, Yook JI (2011) A p53/miRNA-34 axis regulates Snaill-dependent cancer cell epithelial-mesenchymal transition. J. Cell Biol. 195: 417433. http://doi.org/10.1083/jcb.201103097

Kitagawa K, Shigemura K, Sung S-Y, Chen K-C, Huang C-C, Chiang Y-T, Liu M-C, Huang T-W, Yamamichi F, Shirakawa T, Fujisawa M (2019) Possible correlation of sonic hedgehog signaling with epithelial-mesenchymal transition in muscle-invasive bladder cancer progression. J. Cancer Res. Clin. Oncol. 145: 2261-2271. http://doi. org/10.1007/s00432-019-02987-z

Kopan R, Ilagan MXG (2009) The canonical notch signaling pathway: unfolding the activation mechanism. Cell 137: 216-233. http://doi. org/10.1016/i.cell.2009.03.045

Korpal M, Lee ES, Hu G, Kang Y (2008) The miR-200 family inhibits epithelial-mesenchymal transition and cancer cell migration by direct targeting of E-cadherin transcriptional repressors ZEB1 and ZEB2. J. Biol. Chem. 283: 14910-14914. http://doi.org/10.1074/jbc. C800074200

Kouzarides T (2007) Chromatin modifications and their function. Cell 128: 693-705. http://doi.org/10.1016/j.cell.2007.02.005

Kumarswamy R, Mudduluru G, Ceppi P, Muppala S, Kozlowski M, Niklinski J, Papotti M, Allgayer H (2012) MicroRNA-30a inhibits epithelial-to-mesenchymal transition by targeting Snail and is downregulated in non-small cell lung cancer. Int. J. Cancer 130: 2044 2053. http://doi.org/10.1002/ijc.26218

Lamouille S, Xu J, Derynck R (2014) Fakultas Psikologi Dan Sosial Budaya Universitas Islam Indonesia Yogyakarta. Nat. Rev. Mol. Cell Biol. 15: 178-196. http://doi.org/10.1038/nrm3758.Molecular

Le PN, Keysar SB, Miller B, Eagles JR, Chimed TS, Reisinger J, Gomez KE, Nieto C, Jackson BC, Somerset HL, Morton JJ, Wang XJ (2019) Wnt signaling dynamics in head and neck squamous cell cancer tumor-stroma interactions. Mol. Carcinog. 58: 398-410. http://doi.org/10.1002/mc.22937

Lee TK, Poon RTP, Yuen AP, Ling MT, Kwok WK, Wang XH, Wong YC, Guan X, Man K, Chau KL, Fan ST (2006) Twist overexpression correlates with hepatocellular carcinoma metastasis through induction of epithelial-mesenchymal transition. Clin. Cancer Res. 12: 5369-5376. http://doi.org/10.1158/1078-0432.CCR-05-2722

Li H, Xu L, Li C, Zhao L, Ma Y, Zheng H, Li Z, Zhang Y, Wang R, Liu Y, Qu X (2014a) Ubiquitin ligase Cbl-b represses IGF-I-induced epithelial mesenchymal transition via ZEB2 and microRNA200c regulation in gastric cancer cells. Mol. Cancer 13: 136. http:// doi.org/10.1186/1476-4598-13-136

Li J, Yu H, Xi M, Ma D, Lu X (2015) The SNAI1 3'UTR functions as a sponge for multiple migration-/invasion-related microRNAs. Tumor Biol. 36: 1067-1072. http://doi.org/10.1007/s13277-014-2733-z

Li J, Yuan J, Yuan X, Zhao J, Zhang Z, Weng L, Liu J (2016) MicroRNA-200b inhibits the growth and metastasis of glioma cells via targeting ZEB2. Int. J. Oncol. 48: 541-550. http://doi.org/10.3892/ ijo.2015.3267

Li L-Z, Zhang CZ, Liu L-L, Yi C, Lu S-X, Zhou X, Zhang Z-J, Peng Y-H, Yang Y-Z, Yun J-P (2014b) miR-720 inhibits tumor invasion and migration in breast cancer by targeting TWIST1. Carcinogenesis 35: 469-478. http://doi.org/10.1093/carcin/bgt330

Li Q, Lai Q, He C, Fang Y, Yan Q, Zhang Y, Wang X, Gu C, Wang Y, Ye L, Han L, Lin X, Chen J, Cai J, Li A, Liu S (2019) RUNX1 promotes tumour metastasis by activating the $\mathrm{Wnt} / \beta$-catenin signalling pathway and EMT in colorectal cancer. J. Exp. Clin. Cancer Res. 38: 334. http://doi.org/10.1186/s13046-019-1330-9

Liao H, Bai Y, Qiu S, Zheng L, Huang L, Liu T, Wang X, Liu Y, Xu N, Yan X, Guo H (2015) MiR-203 downregulation is responsible for chemoresistance in human glioblastoma by promoting epithelialmesenchymal transition via SNAI2. Oncotarget 6: 8914-8928. http:// doi.org/10.18632/oncotarget.3563

Lin X, Yang Z, Zhang P, Liu Y, Shao G (2016) miR-154 inhibits migration and invasion of human non-small cell lung cancer by targeting ZEB2. Oncol. Lett. 12: 301-306. http://doi.org/10.3892/ ol.2016.4577

Liu M, Liu L, Bai M, Zhang L, Ma F, Yang X, Sun S (2018) Hypoxia-induced activation of Twist/miR-214/E-cadherin axis promotes renal tubular epithelial cell mesenchymal transition and renal fibrosis. Biochem. Biophys. Res. Commun. 495: 2324-2330. http://doi. org/10.1016/j.bbrc.2017.12.130

Liu MX, Siu MKY, Liu SS, Yam JWP, Ngan HYS, Chan DW (2014) Epigenetic silencing of microRNA-199b-5p is associated with acquired chemoresistance via activation of JAG1-Notch1 signaling in ovarian cancer. Oncotarget 5: 944-958. http://doi.org/10.18632/oncotarget.1458

Liu Y-N, Yin JJ, Abou-Kheir W, Hynes PG, Casey OM, Fang L, Yi M, Stephens RM, Seng V, Sheppard-Tillman H, Martin P, Kelly K (2013a) MiR-1 and miR-200 inhibit EMT via Slug-dependent and tumorigenesis via Slug-independent mechanisms. Oncogene 32: 296306. http://doi.org/10.1038/onc.2012.58

Liu Y-N, Yin JJ, Abou-Kheir W, Hynes PG, Casey OM, Fang L, Yi M, Stephens RM, Seng V, Sheppard-Tillman H, Martin P, Kelly K (2013b) MiR-1 and miR-200 inhibit EMT via Slug-dependent and tumorigenesis via Slug-independent mechanisms. Oncogene 32: 296306. http://doi.org/10.1038/onc.2012.58 
Lu W, Kang Y (2019) Epithelial-Mesenchymal Plasticity in Cancer Progression and Metastasis. Dev. Cell 49: 361-374. http://doi. org/10.1016/j.devcel.2019.04.010

Lu J, Getz G, Miska EA, Alvarez-Saavedra E, Lamb J, Peck D, Sweet-Cordero A, Ebert BL, Mak RH, Ferrando AA, e Downing JR, Jacks T, Horvitz HR, Golub TR (2005) MicroRNA expression profiles classify human cancers. Nature 435: 834-838. http://doi. org/10.1038/nature03702

Ma L, Young J, Prabhala H, Pan E, Mestdagh P, Muth D, TeruyaFeldstein J, Reinhardt F, Onder TT, Valastyan S, Westermann F, Speleman F, Vandesompele J, Weinberg RA (2010) miR-9, a MYC/ MYCN-activated microRNA, regulates E-cadherin and cancer metastasis. Nat. Cell Biol. 12: 247-256. http://doi.org/10.1038/ncb2024

Ma X, Sheng T, Zhang Y, Zhang X, He J, Huang S, Chen K, Sultz J, Adegboyega PA, Zhang H, Xie J 2006) Hedgehog signaling is activated in subsets of esophageal cancers. Int. J. Cancer 118: 139-148. http://doi.org/10.1002/ijc.21295

Martello G, Rosato A, Ferrari F, Manfrin A, Cordenonsi M, Dupont S, Enzo E, Guzzardo V, Rondina M, Spruce T, Parenti AR, Daidone MG, Bicciato S, Piccolo S (2010) A MicroRNA targeting dicer for metastasis control. Cell 141: 1195-1207. http://doi.org/10.1016/j. cell.2010.05.017

McDonald OG, Wu H, Timp W, Doi A, Feinberg AP (2011) Genome-scale epigenetic reprogramming during epithelial-to-mesenchymal transition. Nat. Struct. Mol. Biol. 18: 867-874. http://doi, org/10.1038/nsmb.2084

Merritt WM, Lin YG, Han LY, Kamat AA, Spannuth WA, Schmandt R, Urbauer D, Pennacchio LA, Cheng JF, Nick AM, Deavers MT, Mourad-Zeidan A, Wang H, Mueller P, Lenburg ME, Gray JW, Mok S, Birrer MJ, Lopez-Berestein G, Coleman RL, BarEli M, Sood AK (2008) Dicer, Drosha, and outcomes in patients with ovarian cancer. N. Engl. J. Med. 359: 2641-2650. http://doi. org/10.1056/NEJMoa0803785

Miroshnichenko S, Patutina O (2019) Enhanced inhibition of tumorigenesis using combinations of miRNA-targeted therapeutics. Front. Pharmacol. 10: 488. http://doi.org/10.3389/fphar.2019.00488

Moes M, Le Béchec A, Crespo I, Laurini C, Halavatyi A, Vetter G, Del Sol A, Friederich E (2012) A novel network integrating a miRNA-203/SNAI1 feedback loop which regulates epithelial to mesenchymal transition. PLoS One 7: e35440. http://doi.org/10.1371/ journal.pone. 0035440

Mohr AM, Mott JL (2015) Overview of microRNA biology. Semin. Liver Dis. 35: 3-11. http://doi.org/10.1055/s-0034-1397344

Natsuizaka M, Whelan KA, Kagawa S, Tanaka K, Giroux V, Chandramouleeswaran PM, Long A, Sahu V, Darling DS, Que J, Yang Y, Katz JP, Wileyto EP, Basu D, Kita Y, Natsugoe S, Naganuma S, Klein-Szanto AJ, Diehl JA, Bass AJ, Wong KK7, Rustgi AK, Nakagawa H (2017) Interplay between Notch1 and Notch3 promotes EMT and tumor initiation in squamous cell carcinoma. Nat. Commun. 8. http://doi.org/10.1038/s41467-017-01500-9

O’Donnell KA, Wentzel EA, Zeller KI, Dang C V, Mendell JT (2005) c-Myc-regulated microRNAs modulate E2F1 expression. Nature 435: 839-843. http://doi.org/10.1038/nature03677

Pai SI, Lin YY, Macaes B, Meneshian A, Hung CF, Wu TC (2006) Prospects of RNA interference therapy for cancer. Gene Ther. 13: 464-477. http://doi.org/10.1038/sj.gt.3302694

Pan Y, Li J, Zhang Y, Wang N, Liang H, Liu Y, Zhang C-Y, Zen K, Gu H (2016) Slug-upregulated miR-221 promotes breast cancer progression through suppressing E-cadherin expression. Sci. Rep. 6: 25798. http://doi.org/10.1038/srep25798

Papadimitriou E, Vasilaki E, Vorvis C, Iliopoulos D, Moustakas A, Kardassis D, Stournaras C (2012) Differential regulation of the two RhoA-specific GEF isoforms Net1/Net1A by TGF- $\beta$ and miR-24: role in epithelial-to-mesenchymal transition. Oncogene 31: 2862-2875. http://doi.org/10.1038/onc.2011.457

Pavlova N, Thompson C (2016) The emerging hallmarks of cancer metabolism. Cell Metab 23: 27-47. http://doi.org/10.1016/j. cmet.2015.12.006.THF

Pei D, Shu X, Gassama-Diagne A, Thiery JP (2019) Mesenchymal-epithelial transition in development and reprogramming. Nat. Cell Biol. 21: 44-53. http://doi.org/10.1038/s41556-018-0195-z

Peinado H, Olmeda D, Cano A (2007) Snail, ZEB and bHLH factors in tumour progression: An alliance against the epithelial phenotype? Nat. Rev. Cancer 7: 415-428. http://doi.org/10.1038/nrc2131

Petrova YI, Schecterson L, Gumbiner BM (2016) Roles for E-cadherin cell surface regulation in cancer. Mol. Biol. Cell 27: 3233-3244. http:/ / doi.org/10.1091/mbc.E16-01-0058

Pieraccioli M, Imbastari F, Antonov A, Melino G, Raschellà G (2013) Activation of miR200 by c-Myb depends on ZEB1 expression and miR200 promoter methylation. Cell Cycle 12: 2309-2320. http://doi. org $/ 10.4161 /$ cc. 25405

Prieto-García E, Díaz-García CV, García-Ruiz I, Agulló-Ortuño MT (2017) Epithelial-to-mesenchymal transition in tumor progression. Med. Oncol. 34. http://doi.org/10.1007/s12032-017-0980-8

Qi J, Yu Y, Öztürk ÖA, Holland JD, Besser D, Fritzmann J, WulfGoldenberg A, Eckert K, Fichtner I, Birchmeier W (2016) New
Wnt/ $\beta$-catenin target genes promote experimental metastasis and migration of colorectal cancer cells through different signals. Gut 65: 1690-1701. http://doi.org/10.1136/gutjnl-2014-307900

Qu J, Li M, An J, Zhao B, Zhong W, Gu Q, Cao L, Yang H, Hu C (2015) MicroRNA-33b inhibits lung adenocarcinoma cell growth, invasion, and epithelial-mesenchymal transition by suppressing Wnt/ $\beta$-catenin/ZEB1 signaling. Int. J. Oncol. 47: 2141-2152. http:// doi.org/10.3892/ijo.2015.3187

Reid G, Pel ME, Kirschner MB, Cheng YY, Mugridge N, Weiss J, Williams M, Wright C, Edelman JJB, Vallely MP, McCaughan BC, Klebe S, Brahmbhatt H, MacDiarmid JA, van Zandwijk N (2013) Restoring expression of miR-16: A novel approach to therapy for malignant pleural mesothelioma. Ann. Oncol. 24: 3128-3135. http:// doi.org/10.1093/annonc/mdt412

Reinhart BJ1, Slack FJ, Basson M, Pasquinelli AE, Bettinger JC, Rougvie AE, Horvitz HR RG (2000) The 21-nucleotide let-7 RNA regulates developmental timing in Caenorbabditis elegans. Nature 403: 901-906

Ryan B, Faupel-Badger J (2016) The hallmarks of premalignant conditions: a molecular basis for cancer prevention. Semin. Oncol. 43: 22-35. http://doi.org/10.1053/j.seminoncol.2015.09.007. The

Saad S, Stanners SR, Yong R, Tang O, Pollock CA (2010) Notch mediated epithelial to mesenchymal transformation is associated with increased expression of the Snail transcription factor. Int. J. Biochem. Cell Biol. 42: 1115-1122. http://doi.org/10.1016/j.biocel.2010.03.016

Sandberg R, Neilson JR, Sarma A, Sharp PA, Burge CB (2008) Proliferating cells express mRNAs with shortened 3' untranslated regions and fewer microRNA target sites. Science 320: 1643-1647. http:// doi.org/10.1126/science.1155390

Schwab RHM, Amin N, Flanagan DJ, Johanson TM, Phesse TJ, Vincan E (2018) Wnt is necessary for mesenchymal to epithelial transition in colorectal cancer cells. Dev. Dyn. 247: 521-530. http://doi. org/10.1002/dvdy

Selth LA, Das R, Townley SL, Coutinho I, Hanson AR, Centenera MM, Stylianou N, Sweeney K, Soekmadji C, Jovanovic L, Nelson CC, Zoubeidi A, Butler LM, Goodall GJ, Hollier BG, Gregory PA, Tilley WD (2017) A ZEB1-miR-375-YAP1 pathway regulates epithelial plasticity in prostate cancer. Oncogene 36: $24-34$. http://doi. org/10.1038/onc.2016.185

Serrano-Gomez SJ, Maziveyi M, Alahari SK (2016) Regulation of epithelial-mesenchymal transition through epigenetic and post-translational modifications. Mol. Cancer 15: 1-14: http://doi.org/10.1186/ s12943-016-0502-x

Shan Y, Zhang L, Bao Y, Li B, He C, Gao M, Feng X, Xu W, Zhang X, Wang S (2013) Epithelial-mesenchymal transition, a novel target of sulforaphane via COX-2/MMP2, 9/Snail, ZEB1 and miR-200c/ ZEB1 pathways in human bladder cancer cells. J. Nutr. Biochem. 24: 1062-1069. http://doi.org/10.1016/j.jnutbio.2012.08.004

Sheng T, Li C, Zhang X, Chi S, He N, Chen K, McCormick F, Gatalica Z, Xie J (2004) Activation of the hedgehog pathway in advanced prostate cancer. Mol. Cancer 3: 29. http://doi.org/10.1186/14764598-3-29

Shenouda SK, Alahari SK (2009) MicroRNA function in cancer: Oncogene or a tumor suppressor? Cancer Metastasis Rev. 28: 369-378. http://doi.org/10.1007/s10555-009-9188-5

Sherwood L, and Parris E (1971) Tumor angiogenesis: therapeutic implication. $N$ Engl J Med 285: 1182-1186

Shi Z-M, Wang L, Shen H, Jiang C-F, Ge X, Li D-M, Wen Y-Y, Sun H-R, Pan M-H, Li W, Shu YQ, Liu LZ, Peiper SC, He J, Jiang $\mathrm{BH}$ (2017) Downregulation of miR-218 contributes to epithelialmesenchymal transition and tumor metastasis in lung cancer by targeting Slug/ZEB2 signaling. Oncogene 36: 2577-2588. http://doi. org/10.1038/onc. 2016.414

Shioiri M, Shida T, Koda K, Oda K, Seike K, Nishimura M, Takano S, Miyazaki M (2006) Slug expression is an independent prognostic parameter for poor survival in colorectal carcinoma patients. $\mathrm{Br}$. J. Cancer 94: 1816-1822. http://doi.org/10.1038/sj.bjc.6603193

Siemens H, Jackstadt R, Hünten S, Kaller M, Menssen A, Götz U, Hermeking H (2011) miR-34 and SNAIL form a double-negative feedback loop to regulate epithelial-mesenchymal transitions. Cell Cycle 10: 4256-4271. http://doi.org/10.4161/cc.10.24.18552

Skrzypek K, Kusienicka A, Trzyna E, Szewczyk B, Ulman A, Konieczny P, Adamus T, Badyra B, Kortylewski M, Majka M (2018) SNAIL is a key regulator of alveolar rhabdomyosarcoma tumor growth and differentiation through repression of MYF5 and MYOD function. Cell Death Dis. 9: 643. http://doi.org/10.1038/ s41419-018-0693-8

Stemmer V, De Craene B, Berx G, Behrens J (2008) Snail promotes Wnt target gene expression and interacts with $\beta$-catenin. Oncogene 27: 5075-5080. http://doi.org/10.1038/onc. 2008.140

Stone RC, Pastar I, Ojeh N, Chen V, Liu S, Garzon KI, TomicCanic M (2016) Epithelial-mesenchymal transition in tissue repair and fibrosis. Cell Tissue Res. 365: 495-506. http://doi.org/10.1007/ s00441-016-2464-0

Sun Z, Ou C, Liu J, Chen C, Zhou Q, Yang S, Li G, Wang G, Song J, Li Z, Zhang Z, Yuan W, Li X (2019) YAP1-induced MALAT1 
promotes epithelial-mesenchymal transition and angiogenesis by sponging miR-126-5p in colorectal cancer. Oncogene 38: 2627-2644. http://doi.org/10.1038/s41388-018-0628-y

Suzuki T, Mizutani K, Minami A, Nobutani K, Kurita S, Nagino M, Shimono Y, Takai Y (2014) Suppression of the TGF-31-induced protein expression of SNAI1 and N-cadherin by miR-199a. Genes to Cells 19: 667-675. http://doi.org/10.1111/gtc.12166

Szewczyk B, Skrzypek K, Majka M (2017) Targeting MET receptor in rhabdomyosarcoma: rationale and progress. Curr. Drug Targets 18: 98-107. http://doi.org/10.2174/1389450117666151209124123

Taieb J, Tabernero J, Mini E, Subtil F, Folprecht G, Van Laethem JL, Thaler J, Bridgewater J, Petersen LN, Blons H, Collette L, Van Cutsem E, Rougier P, Salazar R, Bedenne L, Emile J-F, LaurentPuig P, Lepage C (2014) Oxaliplatin, fluorouracil, and leucovorin with or without cetuximab in patients with resected stage III colon cancer (PETACC-8): An open-label, randomised phase 3 trial. Lancet Oncol. 15: 862-873. http:/ /doi.org/10.1016/S1470-2045(14)70227-X

Takigawa Y, Brown AMC (2008) Wnt signaling in liver cancer. Curr. Drug Targets 9: 1013-1024. https://doi. org/10.2174/138945008786786127

Tamura G, Yin J, Wang S, Fleisher AS, Zou T, Abraham JM, Kong D, Smolinski KN, Wilson KT, James SP, Silverberg SG, Nishizuka S, Terashima M, Motoyama T, Meltzer SJ (2000) E-cadherin gene promoter hypermethylation in primary human gastric carcinomas. $J$ Natl. Cancer Inst. 92: 569-573. https://doi.org/10.1093/inci/92.7.569

Tang T, Yang Z, Zhu Q, Wu Y, Sun K, Alahdal M, Zhang Y, Xing Y, Shen Y, Xia T, Xi T, Pan Y, Jin L (2018) Up-regulation of miR-210 induced by a hypoxic microenvironment promotes breast cancer stem cell metastasis, proliferation, and self-renewal by targeting E-cadherin. FASEB J. 32: 6965-6981. http://doi.org/10.1096/ fj. $201801013 \mathrm{R}$

Taube JH, Malouf GG, Lu E, Sphyris N, Vijay V, Ramachandran PP, Ueno KR, Gaur S, Nicoloso MS, Rossi S, Herschkowitz JI, Rosen JM, Issa JP, Calin GA, Chang JT, Mani SA (2013) Epigenetic silencing of microRNA-203 is required for EMT and cancer stem cell properties. Sci. Rep. 3: 2687. http://doi.org/10.1038/srep02687

Tran HD, Luitel K, Kim M, Zhang K, Longmore GD, Tran DD (2014) Transient SNAIL1 expression is necessary for metastatic competence in breast cancer. Cancer Res. 74: 6330-6340. http://doi. org/10.1158/0008-5472.CAN-14-0923

Tsai JH, Yang J (2013) Epithelial-mesenchymal plasticity in carcinoma metastasis. Genes Dev. 27: 2192-2206. http://doi.org/10.1101/ $\operatorname{gad} .225334 .113$

Tsai JH, Donaher JL, Murphy DA, Chau S, Yang J (2012) Spatiotemporal regulation of epithelial-mesenchymal transition is essential for squamous cell carcinoma metastasis. Cancer Cell 22: 725-736. http:// doi.org/10.1016/j.ccr.2012.09.022

Vandewalle C, Comijn J, De Craene B, Vermassen P, Bruyneel E, Andersen H, Tulchinsky E, Van Roy F, Berx G (2005) SIP1/ZEB2 induces EMT by repressing genes of different epithelial cell-cell junctions. Nucleic Acids Res. 33: 6566-6578. http://doi.org/10.1093/ nar/gki965

Wang S-C, Lin X-L, Li J, Zhang T-T, Wang H-Y, Shi J-W, Yang S, Zhao W-T, Xie R-Y, Wei F, Qin YJ, Chen L, Yang J, Yao KT, Xiao D (2014) MicroRNA-122 triggers mesenchymal-epithelial transition and suppresses hepatocellular carcinoma cell motility and invasion by targeting RhoA. PLoS One 9: e101330. http://doi. org/10.1371/journal.pone.0101330

Wang Y, Sun B, Zhao X, Zhao N, Sun R, Zhu D, Zhang Y, Li Y, Gu Q, Dong X, Wang M, An J (2016) Twist1-related miR-26b-5p suppresses epithelial-mesenchymal transition, migration and invasion by targeting SMAD1 in hepatocellular carcinoma. Oncotarget 7: 24383-24401. http://doi.org/10.18632/oncotarget.8328

Weinberg R (1994) Oncogenes and tumor suppressor genes. CA Cancer J Clin 44: 160-170. https://doi.org/10.3322/canjclin.44.3.160

Whitehead KA, Langer R, Anderson DG (2009) Knocking down barriers: Advances in siRNA delivery. Nat. Rev. Drug Discov. 8: 129-138. http://doi.org/10.1038/nrd2742

Wijnhoven BPL, Dinjens WNM, Pignatelli M (2000) E-cadherin catenin cel cell adhesion complex and human cancer. Br. J. Surg. 87: 992-1005. http://doi.org/10.1046/j.1365-2168.2000.01513.x

Wu ZQ, Li XY, Hu CY, Ford M, Kleer CG, Weiss SJ (2012) Canonical Wnt signaling regulates Slug activity and links epithelial-mesenchymal transition with epigenetic Breast Cancer 1, Early Onset (BRCA1) repression. Proc. Natl. Acad. Sci. U. S. A. 109: 1665416659. http://doi.org/10.1073/pnas.1205822109

Xiao B, Shi X, Bai J (2018) miR-30a regulates the proliferation and invasion of breast cancer cells by targeting Snail. Oncol. Lett. 17: 406-413. http://doi.org/10.3892/ol.2018.9552

Xiao F, Bai Y, Chen Z, Li Y, Luo L, Huang J, Yang J, Liao H, Guo L (2014) Downregulation of HOXA1 gene affects small cell lung cancer cell survival and chemoresistance under the regulation of miR-100. Eur. J. Cancer 50: 1541-1554. http://doi.org/10.1016/j. ejca.2014.01.024

Xiao J-N, Yan T-H, Yu R-M, Gao Y, Zeng W-L, Lu S-W, Que H-X, Liu Z-P, Jiang J-H (2017) Long non-coding RNA UCA1 regulates the expression of Snail2 by miR-203 to promote hepatocellular carcinoma progression. J. Cancer Res. Clin. Oncol. 143: 981-990. http:// doi.org/10.1007/s00432-017-2370-1

Xiong W-C, Han N, Wu N, Zhao K-L, Han C, Wang H-X, Ping G-F, Zheng P-F, Feng H, Qin L, He P (2018) Interplay between long noncoding RNA ZEB1-AS1 and miR-101/ZEB1 axis regulates proliferation and migration of colorectal cancer cells. Am. J. Transl. Res. 10: $605-617$

Xu L, Zhang Y, Wang H, Zhang G, Ding Y, Zhao L (2014) Tumor suppressor miR-1 restrains epithelial-mesenchymal transition and metastasis of colorectal carcinoma via the MAPK and PI3K/AKT pathway. J. Transl. Med. 12: 244. http://doi.org/10.1186/s12967014-0244-8

Xu M, Li J, Wang X, Meng S, Shen J, Wang S, Xu X, Xie B, Liu B, Xie L (2018) MiR-22 suppresses epithelial-mesenchymal transition in bladder cancer by inhibiting Snail and MAPK1/Slug/vimentin feedback loop. Cell Death Dis. 9: 209. http://doi.org/10.1038/ s41419-017-0206-1

Xu Q, Krause M, Samoylenko A, Vainio S (2016) Wnt signaling in renal cell carcinoma. Cancers (Basel). 8. http://doi.org/10.3390/cancers 8060057

Xu Q, Duan H, Gan L, Liu X, Chen F, Shen X, Tang Y-Q, Wang S (2017a) MicroRNA-1291 promotes endometrial fibrosis by regulating the ArhGAP29-RhoA/ROCK1 signaling pathway in a murine model. Mol. Med. Rep. 16: 4501-4510. http://doi.org/10.3892/ mmr.2017.7210

Xu Y, Jin J, Liu Y, Huang Z, Deng Y, You T, Zhou T, Si J, Zhuo W (2014) Snail-regulated MiR-375 inhibits migration and invasion of gastric cancer cells by targeting JAK2. PLoS One 9: e99516. http:// doi.org/10.1371/journal.pone.0099516

Xu Y, Lee DK, Feng Z, Xu Y, Bu W, Li Y, Liao L, Xu J (2017) Breast tumor cell-specific knockout of Twist1 inhibits cancer cell plasticity, dissemination, and lung metastasis in mice. Proc. Natl. Acad. Sci. U. S. A. 114: 11494-11499. http://doi.org/10.1073/ pnas.1618091114

Yan D, Dong XDE, Chen X, Wang L, Lu C, Wang J, Qu J, Tu L (2009) MicroRNA-1/206 targets c-Met and inhibits rhabdomyosarcoma development. J. Biol. Chem. 284: 29596-29604. http://doi. org/10.1074/jbc.M109.020511

Yang MH, Wu MZ, Chiou SH, Chen PM, Chang SY, Liu CJ, Teng SC, Wu KJ (2008) Direct regulation of TWIST by HIF-1 $\alpha$ promotes metastasis. Nat. Cell Biol. 10: 295-305. http://doi.org/10.1038/ ncb1691

Yang J, Mani S, Donaher J, Ramaswamy S, Itzykson R, Come C, Savagner P, Gitelman I, Richardson A, Weinberg RA (2004) Twist, a master regulator of morphogenesis, plays an essential role in tumor metastasis. Cell 117: 927-939. https://doi.org/10.1016/j. cell.2004.06.006

Yook JI, Li XY, Ota I, Hu C, Kim HS, Kim NH, Cha SY, Ryu JK, Choi YJ, Kim J, Fearon ER, Weiss SJ (2006) A Wnt-Axin2-GSK3 $\beta$ cascade regulates Snail1 activity in breast cancer cells. Nat. Cell Biol. 8: 1398-1406. http://doi.org/10.1038/ncb1508

Yoshiura K, Kanai Y, Ochiai A, Shimoyama Y, Sugimura T, Hirohashi S (1995) Silencing of the E-cadherin invasion-suppressor gene by $\mathrm{CpG}$ methylation in human carcinomas. Proc. Natl. Acad. Sci U. S. A. 92: 7416-7419. https://doi.org/10.1073/pnas.92.16.7416

You J, Li Y, Fang N, Liu B, Zu L, Chang R, Li X, Zhou Q (2014) MiR-132 suppresses the migration and invasion of lung cancer cells via targeting the EMT regulator ZEB2. PLoS One 9: e91827. http:// doi.org/10.1371/journal.pone.0091827

Yu F, Lu Z, Chen B, Wu X, Dong P, Zheng J (2015a) Salvianolic acid B-induced microRNA-152 inhibits liver fibrosis by attenuating DNMT1-mediated Patched1 methylation. J. Cell. Mol. Med. 19: 2617-2632. http://doi.org/10.1111/jcmm.12655

Yu J, Xie F, Bao X, Chen W, Xu Q (2014) miR-300 inhibits epithelial to mesenchymal transition and metastasis by targeting Twist in human epithelial cancer. Mol. Cancer 13: 121. http://doi. org/10.1186/1476-4598-13-121

Yu Y, Zhao Y, Sun X-H, Ge J, Zhang B, Wang X, Cao X-C (2015b) Down-regulation of miR-129-5p via the Twist1-Snail feedback loop stimulates the epithelial-mesenchymal transition and is associated with poor prognosis in breast cancer. Oncotarget 6: 34423-34436. http://doi.org/10.18632/oncotarget.5406

Yuan J, Yang F, Wang F, Ma J, Guo Y, Tao Q, Liu F, Pan W, Wang T, Zhou CC, Wang SB, Wang YZ, Yang Y, Yang N, Zhou WP, Yang GS, Sun SH (2014a) A long noncoding RNA activated by TGF- $\beta$ promotes the invasion-metastasis cascade in hepatocellular carcinoma. Cancer Cell 25: 666-681. http://doi.org/10.1016/j. ccr.2014.03.010

Yuan X, Wu H, Han N, Xu H, Chu Q, Yu S, Chen Y, Wu K (2014) Notch signaling and EMT in non-small cell lung cancer: Biological significance and therapeutic application. J. Hematol. Oncol. 7: 87. http://doi.org/10.1186/s13045-014-0087-z

van Zandwijk N, Pavlakis N, Kao SC, Linton A, Boyer MJ, Clarke S, Huynh Y, Chrzanowska A, Fulham MJ, Bailey DL, Cooper WA, Kritharides L, Ridley L, Pattison AT, MacDiarmid J, Brahmbhatt 
H, Reid G (2017) Safety and activity of microRNA-loaded minicells in patients with recurrent malignant pleural mesothelioma: a firstin-man, phase 1, open-label, dose-escalation study. Lancet Oncol. 18: 1386-1396. http://doi.org/10.1016/S1470-2045(17)30621-6

Zhan T, Rindtorff N, Boutros M (2017) Wnt signaling in cancer. Oncogene 36: 1461-1473. http://doi.org/10.1038/onc.2016.304

Zhang B, Pan X, Cobb GP, Anderson TA (2007) microRNAs as oncogenes and tumor suppressors. Dev. Biol. 302: 1-12. http://doi. org/10.1016/j.ydbio.2006.08.028

Zhang H-F, Xu L-Y, Li E-M (2014) A family of pleiotropically acting MicroRNAs in cancer progression, miR-200: Potential cancer therapeutic targets. Curr. Pharm. Des. 20: 1896-1903. http://doi.org/10.21 74/13816128113199990519

Zhang L, Sun J, Wang B, Ren J-C, Su W, Zhang T (2015) MicroRNA-10b triggers the epithelial-mesenchymal transition (EMT) of laryngeal carcinoma Hep-2 cells by directly targeting the E-cadherin. Appl. Biochem. Biotechnol. 176: 33-44. http://doi.org/10.1007/s12010015-1505-6

Zhang X, Wei C, Li J, Liu J, Qu J (2017) MicroRNA-361-5p inhibits epithelial-to-mesenchymal transition of glioma cells through targeting Twist1. Oncol. Rep. 37: 1849-1856. http://doi.org/10.3892/ or.2017.5406

Zhang Z, Zhang B, Li W, Fu L, Fu L, Zhu Z, Dong J-T (2011) Epigenetic Silencing of miR-203 Upregulates SNAI2 and contributes to the invasiveness of malignant breast cancer cells. Genes Cancer 2: 782-791. http://doi.org/10.1177/1947601911429743

Zhao L, Li R, Xu S, Li Y, Zhao P, Dong W, Liu Z, Zhao Q, Tan B (2018) Tumor suppressor miR-128-3p inhibits metastasis and epithelial-mesenchymal transition by targeting ZEB1 in esophageal squamous-cell cancer. Acta Biochim. Biophys. Sin. (Shanghai). 50: 171180. http://doi.org/10.1093/abbs/gmx132

Zhao N, Sun H, Sun B, Zhu D, Zhao X, Wang Y, Gu Q, Dong X, Liu F, Zhang Y, Li X (2016) miR-27a-3p suppresses tumor metastasis and VM by down-regulating VE-cadherin expression and inhibiting EMT: an essential role for Twist-1 in HCC. Sci. Rep. 6: 23091. http://doi.org/10.1038/srep23091

Zheng M, Jiang Y, Chen W, Li K, Liu X, Gao S, Feng H, Wang S, Jiang J, Ma X, Cen X, Tang YJ, Chen Y, Lin YF, Tang YL, Liang XH (2015) Snail and Slug collaborate on EMT and tumor metastasis through miR-101-mediated EZH2 axis in oral tongue squamous cell carcinoma. Oncotarget 6: 6797-6810. http://doi.org/10.18632/ oncotarget. 3180

Zheng Y-B, Luo H-P, Shi Q, Hao Z-N, Ding Y, Wang Q-S, Li S-B, Xiao G-C, Tong S-L (2014) miR-132 inhibits colorectal cancer invasion and metastasis via directly targeting ZEB2. World J. Gastroenterol. 20: 6515-6522. http://doi.org/10.3748/wjg.v20.i21.6515 